International Journal of Agriculture, Environment and Bioresearch

Vol. 5, No. 04; 2020

ISSN: $2456-8643$

\title{
FORESTRY INFORMATION NEEDS OF NON TIMBER FOREST PRODUCTS GATHERERS IN GAMBARI FOREST ENVIRONMENT, OYO STATE NIGERIA
}

\author{
Adeoye A.S., Abegunrin O.O., Oke O.O, Ogunwale O.G. and Jatto K.A. \\ Department of Agricultural Extension and Management \\ Federal College of Forestry, P.M.B. 5087, Ibadan, Nigeria \\ https://doi.org/10.35410/IJAEB.2020.5535
}

\begin{abstract}
The Non-Timber Forest Products play an important role in livelihoods sustainability of dwellers around forest environment. Therefore, information needs arise due to dearth of information on practices in the NTFPs sector. The NTFPs gatherers' commitment to information seeking however will facilitate sustainable utilization of non-timber resources of the forest. This study was carried out in Gambari forest environment, Oyo State to examine forestry information needs of non-timber forest products gatherers. Purposive sampling procedure and proportionate sample to size was used to select 93 NTFPs gatherers. The data for the study were analyzed with both descriptive and inferential analytical tools. The findings of the study showed male (58.4\%) dominant in NTFPs utilization and in seeking for information about practices in the sector, and $60.2 \%$ of the respondents has level of education significant enough to seek for useful information pertinent to their operations. The result further revealed significant correlation between gatherers' access to information sources and there information needs $(\mathrm{r}=0.643, \mathrm{p}<0.05)$. In conclusion, the findings showed that most gatherers seek for various forms of information which may not be adequate for information needs. It is recommended that government should allocate more forest extension agents and forest guards to help provide and disseminate adequate information needed among the NTFPs gatherers' operations in the Gambari forest environment.
\end{abstract}

Keywords: Forestry, Information needs, Non-Timber Forest Products, Gatherers, Practices.

\section{INTRODUCTION}

Forests provide products for different uses at households and industrial levels (Appiah 2009). These products are grouped into timber and non- timber products (NTFPs). Although timber products are highly valued worldwide, the NTFPs which play an important role in sustaining livelihoods of communities living around forest areas, but have been given minimum attention. In spite of these roles, a major challenge persists in the accurate evaluation of NTFPs as a revenue component for livelihoods of indigenous people (Ngalim, 2011). Therefore, information needs is very important especially to operators in the forestry industry as wood products support the economy and non-wood products support agriculture industry. In the developing nations, NTFPs are considered as safety net that fills the gaps due to a shortfall in agricultural production or other forms of emergencies (Angelsen et al., 2014). Interaction among the rural dwellers is an 
Vol. 5, No. 04; 2020

ISSN: $2456-8643$

essential factor to harnessing necessary information to reducing challenges encountered in forest products utilization and conservation (Hliang et al., 2017). However, decision making among group of people in industries or organizations are greatly influenced by the amount information available to them, but dearth or non-availability of this relevant information exudes wrong decisions (Naveed and Anwar, 2013). Lack of information generally, is hampering the tremendous potentials of NTFPs industry and the operators in the industry (Chamberlain et al., 1998). More often, the major factor that influences information needs among the NTFPs gatherers are sources of information available like radio, friends, neighbours, extension agents, newspapers, posters, articles and the kind of information required such as forest policies, access into the forest, seasonal collection, availability of non wood products etc. The information needs which definitely influence the livelihood and survival of the dwellers of the forest environment can be accessed through information seeking. Access to right information by rural dwellers can help them acquire necessary skills, knowledge, and confidence to fully carry out livelihood activities in their communities (Islam and Ahmed, 2012). In addition, Ogunsawo and Ajala (2002) reported that over 70\% of the country's households depend directly on fuelwood as their main sources of energy with daily consumption estimated at 27.5 million $\mathrm{kg} / \mathrm{day}$. Thus, harvesting and processing of NTFPs in many areas in the country have shifted from subsistence exploitation and sales at the local markets to international cross boundary trade. African forests are source of a variety of NTFPs such as Frits, gums and resins, honey and beeswax, medicinal and aromatic plants, dying and tanning materials, bamboo, and bush meat. Jimoh and Haruna (2007) reported that the NTFPs have potential to contribute around 68\% of total monthly household income within Gambari Forest Reserve, Nigeria. In developing countries, majority of rural household depend on NTFPs such as wild fruits, vegetable, bush meat, firewood to meet some parts of their construction material, health, food and income from selling these products (FAO, 2001). The experts can now involve extension agents and non-governmental organizations to help in sensitizing the non-timber forest products gatherers on information seeking and the benefits derived from sources. Therefore, the study attempts to provide knowledge on forestry information needs of Non-timber forest products gatherers in the Gambari forest environment. The objectives of the study were to examine the personal characteristics of the NTFPs gatherers, identify available non timber forest products in Gambari forest environment, and examine the constraints faced by NTFPs gatherers. The hypotheses for the study are as follows; $\mathbf{H}_{\mathbf{0}} \mathbf{1}$ : there is no significant relationship between the information needs of NTFPs gatherers and availability of NTFPs in the study area, $\mathbf{H}_{0} 2$ : there is no significant relationship between the information needs of ICTs and constraints faced the respondents.

\section{METHODOLOGY}

The study was carried in villages around Gambari Forest Environment located in Oluyole Local Government Area of Oyo state. Gambari is one of the early forest reserves in Oyo state and it is divided into five series namely Onigambari, Busogboro, Onise, Olode. Gambari Forest Reserve is a low land forest reserve. Gambari forest environment is located at an elevation of 82 meters above the sea level with coordinates within latitude $7^{\circ} 7^{\prime} 60^{\prime \prime} \mathrm{N}$ and longitude $3^{\circ} 49^{\prime} 60^{\prime \prime} \mathrm{E}$. The environment is about $17 \mathrm{~km}$ south-east of Ibadan on the Idi-Ayunre, Ijebu-Ode road, Oyo State. It is laid about $2 \mathrm{~km}$ away from the nearest road with some forest fallow. Purposive sampling procedure was used for selection of study population. In Akintola (28), Aba -Igbagbo (30), 
Okeseyi (32), Lagunju (18), and Ajibodu (15) respectively. Proportionate sample to size was used to select $75 \%$ from all the villages. This represents $21,23,24,14$, and 11 respectively to give a total of 93 non timber forest gatherers interviewed by means of a well-structured questionnaire for the study. Data collected were analyzed with descriptive statistics whereas Pearson product moment correlation as inferential statistical tool.

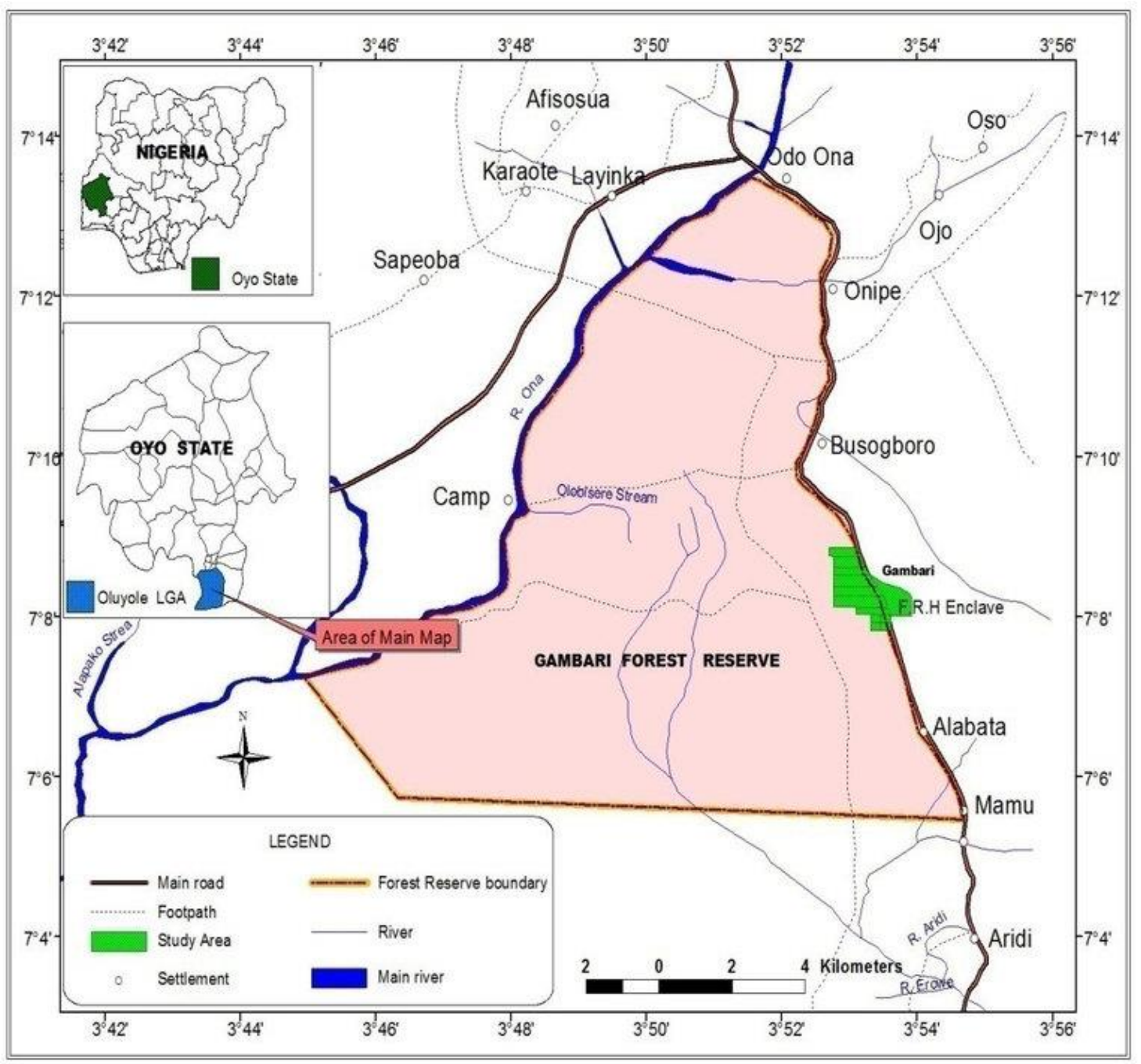

Figure 1: Map of the study area: Gambari Forest Environment

\section{RESULTS}

The results in Table 1 revealed the distribution of NTFPs gatherers based on their selected personal characteristics. The findings showed and exemplified all variables of measurement such as sex, age, marital status, religion, education and other livelihood of the respondents in the study area. 
Table 1: Selected personal characteristics of NTFPs gatherers in the study area (N=93)

\begin{tabular}{|lll|}
\hline Variables & Frequencies & Percentages \\
\hline Sex & & \\
\hline Male & 51 & 54.8 \\
\hline Female & 42 & 45.2 \\
\hline Age & 16 & 17.2 \\
\hline $20-29$ & 34 & 36.6 \\
\hline $30-39$ & 32 & 34.4 \\
\hline $40-49$ & 11 & 11.8 \\
\hline Above 50 & & 15.1 \\
\hline Marital Status & 14 & 74.2 \\
\hline Single & 69 & 3.2 \\
\hline Married & 3 & 7.5 \\
\hline Divorced & 7 & \\
\hline Widow & & 41.9 \\
\hline Religion & 39 & 44.1 \\
\hline Christianity & 41 & 14.0 \\
\hline Islam & 13 & 23.7 \\
\hline Traditional & & 60.2 \\
\hline Educational Level & 22 & 9.6 \\
\hline No formal education & 56 & 6.5 \\
\hline Primary Education & 9 & 73.0 \\
\hline Secondary Education & 6.6 \\
\hline Tertiary Education & 68.4 \\
\hline Other livelihood & & \\
\hline Farming and trading & 68 & \\
\hline Lumbering & 17 & \\
\hline Hunting and fishing & & \\
\hline
\end{tabular}

The result in Table 2 showed the distribution of identified NTFPs by the gatherers based on their information needs in the study area. The distribution depicted the non-timber forest products identified in the study area.

Table 2: Identified non timber forest products by the NTFPs Gatherers (N=93)

\begin{tabular}{|c|c|c|c|}
\hline Variable & Scientific name & Not available & Available \\
\hline Mushroom & Schizophyllum commune & $32(34.4 \%)$ & $61(65.6 \%)$ \\
\hline African giant snail & Achatina achatina & $72(77.4 \%)$ & $21(22.6 \%)$ \\
\hline African locust bean & Parkia biglobosa & $24(25.8 \%)$ & $69(74.2 \%)$ \\
\hline Bamboo & Bambusa vulgaris & $39(41.9 \%)$ & $54(58.1 \%)$ \\
\hline
\end{tabular}


Vol. 5, No. 04; 2020

ISSN: $2456-8643$

\begin{tabular}{|llcc|}
\hline Fuel woods & & $3(3.2 \%)$ & $90(96.8 \%)$ \\
\hline Palm fronds & Elaeis guineensis & $11(11.8 \%)$ & $82(88.2 \%)$ \\
\hline Castor Bean & Ricinus communis & $19(20.4 \%)$ & $74(79.6 \%)$ \\
\hline Physic nut & Jatropha curcas & $13(14.0 \%)$ & $80(86.0 \%)$ \\
\hline Garlic (Ayuu) & Allium sativum & $15(16.1 \%)$ & $78(83.9 \%)$ \\
\hline Iyeye & Spondias mombin & $10(10.8 \%)$ & $83(89.2 \%)$ \\
\hline Fenugreek (Ewedu) & Corchorus olitorius & $17(18.3 \%)$ & $76(81.7 \%)$ \\
\hline Heckel/Bitter Cola & Garcinia kola & $12(12.9 \%)$ & $81(87.1 \%)$ \\
\hline Sweet prayer plant & Thaumatococcus danielli & $7(7.5 \%)$ & $86(92.5 \%)$ \\
\hline Mint leaf & Mentha piperita & $11(11.8 \%)$ & $82(88.2 \%)$ \\
\hline Coral plant (Ogege) & Jatropha multifida & $18(19.4 \%)$ & $75(80.6 \%)$ \\
\hline Cotton leaf (Botuje) & Jatropha gossypifolia & $14(15.1 \%)$ & $79(84.9 \%)$ \\
\hline Sheabutter tree (Ori) & Butyrospermum paradoxa & $23(24.7 \%)$ & $70(75.3 \%)$ \\
\hline Bush mango & Irvingia gabonensis & $5(5.4 \%)$ & $88(94.6 \%)$ \\
\hline Ginger (Ata ile) & Zingiber officinale & $9(9.7 \%)$ & $84(90.3 \%)$ \\
\hline
\end{tabular}

The result in Table 3 showed the distribution of NTFPs Gatherers based on their information needs in the study area. The distribution depicted the types of information needed by the NTFPs Gatherers in the study area.

Table 3: Information needs of NTFPs Gatherers in Gambari Forest Environment (N=93)

\begin{tabular}{|lcc|}
\hline Types of information needs & \multicolumn{1}{c|}{ Essential } & Non-essential \\
\hline Timely access to forest & $78(83.9 \%)$ & $15(16.1 \%)$ \\
\hline Forestry extension information & $34(36.6 \%)$ & $59(63.4 \%)$ \\
\hline Available non-wood products & $89(95.7 \%)$ & $4(4.3 \%)$ \\
\hline Market situation & $68(73.1 \%)$ & $25(26.9 \%)$ \\
\hline Sustainable sales transaction & $82(88.2 \%)$ & $11(11.8 \%)$ \\
\hline Information on season's collection & $81(87.1 \%)$ & $12(12.9 \%)$ \\
\hline Processing/preservation techniques & $79(84.9 \%)$ & $14(15.1 \%)$ \\
\hline Meeting days with forest guards & $28(30.1 \%)$ & $65(69.9 \%)$ \\
\hline Income-generation & $82(88.2 \%)$ & $11(11.8 \%)$ \\
\hline Forest policies & $28(30.1 \%)$ & $65(69.9 \%)$ \\
\hline Risk reduction & $24(25.8 \%)$ & $69(74.2 \%)$ \\
\hline Efficient collection methods & $88(94.6 \%)$ & $5(5.4 \%)$ \\
\hline Reduced transport problem & $73(78.5 \%)$ & $20(21.5 \%)$ \\
\hline Forest gatherers' education & $62(66.7 \%)$ & $31(33.3 \%)$ \\
\hline Forest annual dues & $47(50.5 \%)$ & $46(49.5 \%)$ \\
\hline
\end{tabular}

The result in Table 4 revealed distribution of the constraints experienced by the NTFPs gatherers in the study area. The result depicted the challenges encountered by the NTFPs gatherers in sourcing for information needed for the improvement of their livelihood. 
Table 4: Constraints faced by NTFPs Gatherers to information needs (N=93)

\begin{tabular}{|lccc|}
\hline Constraints & Major constraint & Minor constraint & No constraint \\
\hline Poor timely access to information & $79(63.9 \%)$ & $5(5.4 \%)$ & $9(9.7 \%)$ \\
\hline Erratic power supply & $66(71 \%)$ & $12(12.9 \%)$ & $15(16.1 \%)$ \\
\hline Lack of awareness & $10(10.7 \%)$ & $38(40.9 \%)$ & $45(48.4 \%)$ \\
\hline Negative attitude & $8(8.6 \%)$ & $45(48.4 \%)$ & $40(43.0 \%)$ \\
\hline Poor visit of extension agent & $14(15.1 \%)$ & $56(60.2 \%)$ & $23(24.7 \%)$ \\
\hline Lack of training & $69(74.2 \%)$ & $9(9.7 \%)$ & $15(16.1 \%)$ \\
\hline Insufficient tool for collection & $57(61.3 \%)$ & $21(22.6 \%)$ & $15(16.1 \%)$ \\
\hline Poor finance & $65(69.9 \%)$ & $16(17.2 \%)$ & $12(12.9 \%)$ \\
\hline Lack of preparation & $10(10.8 \%)$ & $11(11.8 \%)$ & $72(77.4 \%)$ \\
\hline
\end{tabular}

The results in Table 5 exemplified the relationship that exists between the identified non-timber forest products, constraints and the information needs of the NTFPs gatherers in the study area.

Table 5: Pearson product moment correlation (PPMC) Analysis of relationship between the information needs of NTFPs gatherers and identified NTFPs and constraints in the study area

\begin{tabular}{|lccc|}
\hline Variable & r-value & p-value & Decision \\
\hline $\begin{array}{l}\text { Information needs versus } \\
\text { Identified NTFPs }\end{array}$ & 0.643 & 0.049 & Significant \\
\hline $\begin{array}{l}\text { Information needs versus } \\
\text { Constraints }\end{array}$ & 0.524 & 0.000 & Significant \\
\hline
\end{tabular}

\section{DISCUSSION}

Table 1 showed the personal characteristics that male gender (58.4\%) NTFPs gatherers were more involved in information seeking in their industry. This implies that both male and female respondents have information needs in the NTFPs industry. This result is line with Tee et al., (2014) that male genders were dominant in the utilization of NTFPs in forest communities. Majority of the gatherers (71.0\%) fall within the age range of 30-49.This implies that most of the gatherers were within the active working age and have agility to seek for information on NTFPs industry. This is in tandem with the submission of Suleiman et al., (2017) that the people across the age bracket of 39-49 were more active and stronger to cope with NTFPs collection from the reserve. Most of the gatherers (74.2\%) were married. This implies that married people in rural communities have responsibility and understand the relevance of information to the success of their industry. This result contradicts FAO (1995) submission that is difficult for local people to have access to information about potential resources in non-timber forest product sector. The 
result also revealed that the NTFPs gatherers practiced both religion, Christianity (41.1\%) and Islam (44.1\%). This implies that both religions were practiced in the study area, and they positively influence their level of information needs. There was no prejudice or discrimination towards the choice of religion by the respondents. The result further showed that majority of the gatherers $(60.2 \%)$ had primary education but they can still read and write in the study area. This implies that low educational status of the gatherers may enhance access to information seeking and necessity for information needs by the gatherers in their industry. Akinbile et al., (2018) supports this result that primary education can enhance access to information among dwellers of forest communities. Majority of the NTFPs gatherers (63.4\%) practiced farming with $14.1 \%$ of them practicing hunting apart from their primary NTFPs collection. This implies that other means of livelihood like farming and hunting will motivate the gatherers on necessary information needed for betterment of their sustainability in the NTFPs industry. This result is line with Nkwatoh et al., (2010) that most NTFPs resources were primarily collected by harvesters, hunters who initiate communication for resource utilization.

The Table 2 revealed that non -timber forest products were identified by majority of the gatherers as available in Gambari forest environment. These identified non-timber products are mushroom, African locust bean, Bamboo, fuel woods, Palm fronds, Castor bean, Physic nut, Garlic, Spondia mombin, Ginger, Sweet prayer plant, Shea butter plant, African rattan palm, bush mango and many more. This result corroborates with the findings of Amusa et al., (2012) that there were abundant NTFPs resources available in Omo forest reserves and Shasha forest reserve in Southwest Nigeria.

The result in Table 3 revealed necessary information needed by the gatherers in the study area. The majority of the NTFPs gatherers mentioned that they needed information on various types of information about NTFPs industry. Many of them indicated timely access to the forest (83.9\%), available non-wood products $(95.7 \%)$, market situation $(73.1 \%)$, processing/preservation information $(84.9 \%)$, forest annual dues $(50.5 \%)$. This implies that majority of the gatherers in Gambari forest environment need information essential to their livelihood sustainability. This is line with the submission of Sunderland (2001) that useful information among NTFPs stakeholders in harvesting and trading was gathered through interpersonal meetings in forest communities.

Table 4 presents the constraints faced by the gatherers to information needs in the study area. The majority of the gatherers $(63.9 \%)$ mentioned that they had problem of timely access to required information, erratic power supply (71.0\%), low level of education $(74.2 \%)$, and poor finance $(69.9 \%)$. They mentioned infrequent visit of extension agents as minor problem experienced by them (60.2\%). This implies that most of the gatherers in Gambari forest environment preferred informal source of information and oral communication channels as a result of low level of education.

\section{Hypotheses Testing}

The result in Table 5 showed the relationship between the information needs of NTFPs gatherers and the identified NTFPs in the study area $(\mathrm{r}=0.643, \mathrm{p}<0.05)$. This implies that the identified NTFPs has a significant relationship with respondents' information needs in Gambari forest 
environment. The results also showed the relationship between the information needs of NTFPs gatherers and the constraints experienced by the respondents $(r=0.524, p<0.05)$. This implies that the constraints encountered by the gatherers have influence on the information needed by them.

\section{CONCLUSION}

The result further showed that majority of the gatherers $(60.2 \%)$ had primary education but they can still read and write in the study area which implies that low educational status of the gatherers may enhance access to information seeking and necessity for information needs by the gatherers in their industry. The findings showed that most gatherers rely on interpersonal communication which may not be adequate for information needs as little access were made to forest extension information and forest guards as a result of low level of education.

\section{RECOMMENDATION}

It is recommended that government should sponsor the training of more forest extension agents and forest guards, and deploy them to various forest reserves in Nigeria as well as Gambari forest environment to help provide and disseminate adequate information needed among the NTFPs gatherers. There is also need to improve on quality and form in which information needed by the NTFPs gatherers is disseminated for improvement on their livelihood to be achieved.

\section{REFERENCES}

Amusa,T.O., Jimoh, S.O., and Azeez, I.O.(2012). Prevalence, Utilization, and Conservation Strategies of Non-Timber Forest Products in Southwestern Zone of Nigeria. Journal of $\begin{array}{lllll}\text { Resources and } \quad \text { Environment. } & \text { Pol.2 } & \text { (1), }\end{array}$ https://article.sapub.org >10.5923.j.re.2012020...

Angelsen A, Jagger P., Babigumira R., Belcher, B., Hogarth, N.J., Bauch S. (2014). Environmental income and Livelihoods: a global Comparative analysis.

Appiah, D.O. (2009) Personifying sustainable rural livelihoods in forest fringe communities inGhana:873-877

Akinbile, L.A., Aminu, O.O. and Kolade, R.I. (2018). Perceived Effect of Climate Change on Forest DependentLivelihoods in Oyo State, Nigeria. .Journal of Agricultural Extension. Vol.22(2). https://dx.doi.org/10.431/jae.v22

Chamberlain, J., Bush, R., and Hammet, A.L. (1998). Non-Timber Forest Products. Forest

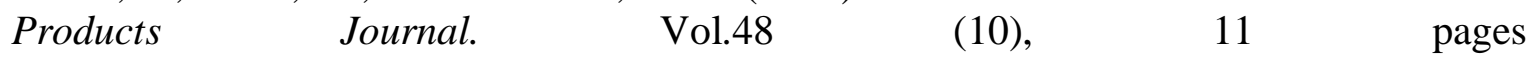
https://www.researchgate.net/publication/292321535

FAO (2001). Resources assessment of Non=wood Forest product: Experienceand biometric principles (eds, Jennifer LG, Kirsti T \& Nell B). FAO, Rome 2001.109Pp.

FAO (2003). Food and Agriculture Organization for the united nations

FAO (1995). Marketing Information Systems for Non-Timber Forest Products. Community Forestry Field Manual 6. Written by Carla Koppell. Edited by Karen Schoonmaker Freudenberg. https://www.fao.org 
Hliang, Z.C., Kamiyama, C., and Saito, O. (2017). Interaction between Rural People's basic needs and forest products: A case study of Katha District of Myanmar. International Journal of Forestry Research. Vol. 2017, Article ID2105012, 18pages. https://doi.org/10.1155/2017/205012

Islam, M.S. and Ahmed, S.M.Z. (2012). The Information needs and information seeking behavior of rural dwellers: A review research. International Federation of Library Association and Institutions Journal. Vol.38 (2), Pp137-147. https://journals.sagepub.com>doi>pdf

Jimoh SO, Hauna EA (2007). Contribution of non timber forest products to household food security and income around Onigambari forest reserve, Oyo State, Nigeria J. Environ.Extens. 6:28-33.

Naveed, M.A. andAnwar, M.A. (2013). Agrultural information needs of Paskistani farmers. Malaysian Journalof Library and Information. Vol.18 (3). Pp13-23

Ngalim OY (2011). Revenue Components and conflicts in the use of natural resources in the peripheral zone Northeast of Korup National pack. Pg 93

Nkwatoh, A.F., Popoola, L., Iyasa, S.M. and Nkwatoh, F.W. (2010). Trade on Non-Timber Forest Products (NTFPs) between Southwest Cameroon and Nigeria. Global Journal of Pure and Applied Sciences. Vol.16(2) https://www.ajol.info

Ogunsanwo, O.Y., Ajala, O.O. (2002). Firewood crises in lagos: Implication on the suburban and rural ecosystem management. Proceeding of the $28^{\text {th }}$ annual conference of Forestry Association of Nigeria at Akure, Ondo State. Pp 257-264.

Suleiman, M.S., Wasonga, V.O., Mbau, J.S., Suleiman, A. and Elhadi, Y.A. (2017). Non-Timber Forest Products and their Contribution to Households Income around Falgore Reserve in Kano, Nigeria. Journal of Ecological Process. Vol.6(23) https://linl.springer.com

Sunderland, T. (2001). Cross River State Community Forestry Project. Final Report of NonTimber Forest Products Advisor. https://Nigeria.wcs.org $>$ DMX $>$ Download

Tee, T.N., Edet, D.I., and Oris, H. (2014). Gender analysis of non-timber forest products utilization by neighbourhood communities of Cross-River National park. Journal of Agriculture,Forestry, and Social Sciences. Vol.12 (1). https://www.researchgate.net 